\title{
Konstruksi Realitas Makam Dewi Sekardadu dalam Komunikasi Pariwisata Pro-Poor di Sidoarjo
}

\author{
Didik Hariyanto*, Djarot Meidi Budi Utomo, Hendra Sukmana, \& Ferry Adhi Dharma \\ Universitas Muhammadiyah Sidoarjo \\ Jl. Mojopahit No. 666B, Sidowayah, Kabupaten Sidoarjo, Jawa Timur, Indonesia \\ *e-mail : didikhariyanto@umsida.ac.id
}

\begin{abstract}
This study aims to determine the reality construction carried out by the community towards Dewi Sekardadu's grave in pro-poor tourism communication. This research method is qualitative with the phenomenological approach of Peter $L$. Berger. The results showed that there was a reality construction in tourism communication that carried out on Dewi Sekardadu's grave. The communication carried out includes three stages (externalization, objectivation, internalization). In the externalization stage, tourism communication emphasizes the Islamic side of Dewi Sekardadu. The tourism communication objectivation stage seeks to build the Tomb of Dewi Sekardadu as an Islamic figure who is accepted by all people because they have received primary socialization from the family. In the internalization stage, tourism communication was developed by making Dewi Sekardau grave a tourism commodity for the surrounding community, especially those of adult age. The existence of tourism communication will support people's knowledge in religious tourism, fulfill tourism support facilities and increase the income of the surrounding community who are currently still working as fish pond keepers and river fishermen due to the lack of socialization and tourism management training from the government.
\end{abstract}

Keywords: Tourism Communication; Construction of Reality; Dewi Sekardadu; Pro-Poor Tourism

\begin{abstract}
ABSTRAK
Penelitian ini bertujuan untuk mengetahui konstruksi realitas yang dilakukan oleh masyarakat terhadap makam Dewi Sekardadu dalam komunikasi pariwisata pro-poor. Metode penelitian ini kualitatif dengan pendekatan fenomenologi Peter L. Berger. Hasil penelitian menunjukkan adanya konstruksi realitas dalam komunikasi pariwisata yang dilakukan terhadap makam Dewi Sekardadu. Komunikasi yang dilakukan meliputi tiga tahapan (ekternalisasi, obyektivasi, internalisasi). Dalam tahap eksternalisasi komunikasi pariwisata lebih menonjolkan sisi Islami dari Dewi Sekardadu. Tahap obyektivasi komunikasi pariwisata berusaha membangun Makam Dewi Sekardadu sebagai tokoh Islam yang diterima oleh seluruh masyarakat karena telah mendapatkan sosialisasi primer dari keluarga. Pada tahap internalisasi komunikasi pariwisata yang dikembangkan dengan menjadikan makam Dewi Sekardau sebagai komoditas pariwisata masyarakat sekitar utamanya masyarakat berusia dewasa. Dengan adanya komunikasi pariwisata akan menunjang pengetahuan masyarakat dalam wisata religi, memenuhi fasilitas penunjang pariwisata serta meningkatkan pendapatan masyarakat sekitar yang saat ini masih berprofesi sebagai penjaga tambak ikan dan nelayan sungai karena kurangnya sosialisasi dan pelatihan manajemen pariwisata dari pemerintah.
\end{abstract}

Kata kunci: Komunikasi Pariwisata; Konstruksi Realitas; Dewi Sekardadu; Pariwisata Pro-Poor. 


\section{Latar Belakang}

Studi ini bertujuan untuk mengetahui konstruksi realitas yang dilakukan oleh masyarakat terhadap makam Dewi Sekardadu dalam komunikasi pariwisata pro-poor sebagai wisata ekoreligi masyarakat Kepetingan, Buduran, Kabupaten Sidoarjo. Fenomena ini dipandang unik karena komoditas pariwisata yang dikembangkan adalah sebuah makam dari sosok yang sampai saat ini menjadi folklor legenda bagi masyarakat pesisir Sidoarjo.

Pengembangan pariwisata eko religi di Indonesia memiliki daya tarik bagi banyak akademisi. Seperti penelitian mengenai pengembangan wisata ekoreligi yang telah dilakukan oleh Ketut Wirata pada tahun 2015 di Pulau Bali. Wirata dalam disertasinya menyebutkan bahwa selama ini masyarakat Bali dan pemerintah setempat mengembangkan wisata ekoreligi berkelanjutan berbasis hukum adat masyarakat Bali sebagai strategi utama yang dinilai berhasil dalam mendatangkan banyak wisatawan (Wirata, 2015).

Strategi pengembang wisata ekoreligi di Bali di atas berbeda dengan strategi yang diberlakukan pada makam Dewi Sekardadu. Masyarakat Kepetingan justru ingin mandiri dalam mengembangkan wisata ekoreligi agar dapat memaksimalkan penghasilan dari sektor pariwisata.

Rukin juga meneliti pengembangan pariwisata di pesisir Sidoarjo, yang itu meliputi makam Dewi Sekardadu. Penelitian ini didasarkan pada fenomena rendahnya perkembangan sektor pariwisata yang terjadi di desa-desa pesisir dalam meningkatkan perekonomian masyarakat. Hal ini mencakup rendahnya pendidikan masyarakat sehingga tidak dapat memanfaatkan potensi wisata yang ada dan minimnya pembangunan infrastruktur dari pemerintah sehingga tidak banyak menunjang pengembangan pariwisata di dusun Kepetingan (Rukin, 2020).

Pariwisata pro rakyat miskin hendaknya juga melibatkan masyarakat sekitar sebagai aktor kunci yang didukung oleh perbaikan modal sosial dan ekokrasi. Salah satu contoh dari keterlibatan masyarakat sebagai aktor adalah wisata kampung warna-warni di Jodipan, Malang, yang bisa mengubah sebuah kampung kumuh menjadi kampung yang indah dan bisa meningkatkan ekonomi masyarakat sekitar (Prasetyanti, 2017).

Berdasarkan hasil observasi ditemukan beberapa ekokrasi yang sudah dilakukan oleh pemerintah untuk pengembangan pariwisata eko-religi di Kepetingan, seperti: pavingisasi jalan darat menuju makam pada tahun 2003, pemugaran makam pada tahun 20 oktober 2002, dan pemberian 3 perahu yang bisa disewakan pada pengunjung yang ingin menempuh jalur sungai dengan pemandangan hutan mangrove. Kendati demikian, ekokrasi tersebut tidak diimbangi dengan setting sosial masyarakat Kepetingan dan strategi komunikasi pariwisata yang baik, sehingga tidak berdampak secara ekonomis pada masyarakat miskin. Dari keseluruhan jumlah keluarga, yakni $99 \mathrm{KK}, 65 \%$ termasuk dalam kategori keluarga miskin. Masyarakat Kepetingan masih mengandalkan tambak dan sungai maupun rawa-rawa sebagai sumber ekonomi mereka, sedangkan sebagain memilih untuk memanfaatkan wisatawan religi untuk membuka warung makanan dan minuman.

Perlu diketahui bahwa lokasi makam Dewi Sekardadu cukup terisolir dan dapat ditempuh melalui jalur darat dan jalur sungai. Waktu yang ditempuh melalui jalan darat berkisar antara 30 sampai 45 menit dengan kecepatan rata-rata 20 
$\mathrm{km} / \mathrm{jam}$ dari jalan aspal desa Sawohan memasuki area tambak menuju dusun Kepetimgan, sedangkan jika ditempuh melalui jalur air dengan menggunakan perahu motor dapat memakan waktu sekitar 45 sampai 60 menit, dengan ongkos rata-rata Rp. 300.000,00 sampai Rp. 400.000,00 /pulang-pergi untuk menyewa satu perahu dari desa Bluru Kidul.

Nilai tambah dari makam Dewi Sekardadu justru datang dari ritual Nyadran yang diadakan oleh desa Bluru Kidul dan Balongdowo pada setiap bulan Ruwah atau Sa'ban. Ritual nyadran menarik minat wisatawan untuk melihat pagelaran nyadran secara langsung dari dusun Kepetingan sehingga para pedagang lokal mendapat penghasilan berlipat ganda.

Pada bulan Ruwah observasi lapangan dilakukan di Dsusun Kepetingan dengan hasil yang menunjukkan adanya wacana pengembangan makam Dewi Sekardadu menjadi wisata ekoreligi oleh masyarakat saat mereka memperingati haul Nyai Dewi Sekardadu pada 03 Mei 2018 di dusun Kepetingan.

Masyarakat Kepetingan telah mengembangkan pariwisata ini secara individu. Beberapa masyarakat bahkan memiliki peziarah prospectus yang secara rutin berziarah ke makam Dewi Sekardadu. Beberapa penduduk yang memiliki modal membuka jasa penjemputan menggunakan perahu, penyediaan catering atau jamuan makan, dan penginapan. Dengan demikian pengembangan wisata ekoreligi di Kepetingan tidak hanya direncanakan secara kolektif, namun sudah dilakukan oleh para pemilik modal, baik modal ekonomi maupun modal sosial yang ada di dusun Kepetingan.

Makam Dewi Sekardadu tidak hanya berada di Dusun Kepetingan. Penelitian ini menemukan ada 4 situs makam Dewi Sekardadu, yakni: 1 di Lamongan, 1 di Gresik, dan 2 di Sidoarjo. Selain terletak di Dusun Kepetingan, makam Dewi Sekardadu juga ada di Dusun Gebang, Desa Gisik Cemandi, Sedati. Jarak antara Dusun Kepetingan dengan Dusun Gebang kurang lebih 20 kilometer. Masyarakat di dua dusun tersebut sama-sama mengklaim bahwa makam yang ada di dusun mereka adalah makam Dewi Sekardadu yang asli dengan menunjukkan kisah folklor yang berbeda.

Masyarakat dusun Kepetingan percaya bahwa jasad Dewi Sekardadu dimakamkan di sana karena jasad tersebut dibawa oleh ikan-ikan keting yang secara ajaib mampu menyeret jasad manusia dari teluk Permisan menuju daratan Kepetingan, sehingga menjadi cikal bakal nama dusun tersebut, yakni Kepetingan atau Ketingan. Sedangkan masyarakat Dusun Gebang percaya bahwa yang dibawa oleh ikan keting ke daratan Kepetingan hanyalah selendang milik Dewi Sekardadu yang secara tidak sengaja tersangkut di sirip atas ikan-ikan tersebut, dan jasadnya secara alami terdampar di sekitaran Desa Banjar Kemuning.

Folklor tersebut terus dikomunikasikan pada generasi muda di masing-masing daerah dan peziarah. Kendati demikian, hasil penelitian menunjukkan bahwa masyarakat Kepetingan lebih aktif dalam menyebarluaskan folklor Dewi Sekardadu dalam bentuk komunikasi pariwisata daripada masyarakat Gebang. Salah satu strategi yang dilaukan oleh masyarakat dusun Kepetingan adalah pertama membangun makam Dewi Sekardadu yang lebih representatif agar layak digunakan sebagai wisata religi, ke dua melakukan branding makam Dewi Sekardadu sebagai bagian dari kerabat wali songo yaitu ibunda Dari Sunan Giri, Ke tiga masyarakat kepetingan 
mengkultuskan makam Dewi Sekardadu dapat membantu hajat para peziarah yang datang ke makam, ke empat sering mengadakan ritual keagamaan dengan mengundang tokoh-tokoh agama atau ulama dari luar daerah yang memiliki banyak pengikut atau santri. Seperti pada ritual Haul Dewi Sekardadu, ritual banjari, dan pengajian-pengajian keagamaan.

Usaha yang dilakukan oleh masyarakat Kepetingan membuahkan hasil positif. Banyak peziarah dari luar daerah berdatangan untuk berziarah ke makam Dewi Sekardadu. Selain itu, situs makam Dewi Sekardadu juga mendapat legitimasi dari Pemerintah Kabupaten Sidoarjo dan menjadi salah satu destinasi wisata religi yang terus dikembangkan.

Komunikasi pariwisata berbasis kearifan lokal seperti yang dilaukan oleh masyarakat Kepetingan di atas merupakan bagian dari praktik komunikasi yang memberikan nuansa baru dalam pengembangan pariwisata (Bakti, Sumartias, Damayanti, \& Nugraha, 2018). Karenanya, penting bagi penelitian ini untuk mengatahui bagaimana konstruksi realitas makam Dewi Sekardadu dalam komunikasi pariwisata yang dilakukan oleh masyarakat untuk mengembangkan pariwisata eko religi pro-poor di dusun Kepetingan.

\section{Metode}

Penelitian ini dilakukan pada bulan april 2018 sampai mei 2018 dan dilanjutkan lagi pada bulan januari 2020 sampai juni 2020, di dusun Kepetingan, desa Sawohan, kecamatan Buduran, kabupaten Sidoarjo, Jawa Timur menggunakan metode kualitatif dengan pendekatan fenomenologi Peter L. Berger. Pemilihan lokasi penelitian didasarkan pada hasil observasi partisipan yang dilakukan di dua tempat, yakni dusun Kepetingan dan Dusun Gebang, Sidoarjo.
Kepetingan dipilih sebagai lokasi penelitian karena ada strategi komunikasi pariwisata yang dilakukan oleh masyarakat dengan cara mengkonstruksi realitas situs makam Dewi Sekardadu menjadi pusat wisata religi di Sidoarjo. Penetapan informan menggunakan teknik snowball sampling, dimulai dari wawancara dengan key informan kepala Desa Sawoan, pemangku makam, tokoh masyarakat dan agama, serta budayawan dan sejarahwan Sidoarjo yang tergabung dalam Komunitas Sidoarjo Masa Kuno.

Implikasi metodologis dan teoritis dari posisi ini dikembangkan oleh Harold Garfinkel sebagai "ethnometodology", yang dianggap sebagai sekularisasi dari fenomenologi; sebuah pendekatan yang membatasi diri pada kritik konvensional positivisme dalam ilmu-ilmu sosial dan menunjukkan kehidupan sehari-hari dari lokus aktor sosial (Harvie, 2011). Kata kunci fenomenologi Berger terletak pada tiga tahapan, yakni: eksternalisasi, obyektivasi, dan internalisasi (Dharma, 2018). Ketiga tahapan atau proses tersebut didapat dari data dokumentasi, observasi partisipan dan wawancara mendalam dengan membuat pertanyaanpertanyaan deskriptif pada masyarakat Kepetingan, pemangku kepentingan di Kepetingan, pemerintah setempat, dan wisatawan yang berkunjung ke makam Dewi Sekardadu. Data yang didapat kemudian dianalisa dan dilakukan triangulasi sumber dan data sebelum disajikan.

\section{Pembahasan}

\section{Tahap Eksternalisasi Sosok Dewi Sekardadu}

Terdapat 3 sosok yang selalu dikaitkan dengan folklor Dewi Sekardadu dalam komunikasi pariwisata berbasis kearifan lokal oleh masyarakat Sidoarjo, yakni: putri dari kerajaan Hindu, isteri seorang Wali, dan Ibu dari seorang Wali. Ketiga 
sosok itu lah yang kemudian dijadikan sebagai dasar pengetahuan oleh masyarakat sekitar untuk mengkeramatkan makam tersebut dan dijadikan sebagai pusat ritual keagamaan. Masyarakat sekitar yang berada di luar dusun Kepetingan, yakni masyarakat desa Bluru Kidul dan Balongdowo menjadikan makam Dewi Sekardadu sebagai pusat ritual nyadran yang dilakukan pada setiap bulan Ruwah atau Sa'ban. Sedangkan masyarakat Kepetingan tidak pernah menggunakan istilah nyadran untuk menyebut aktivitas ritual keagamaan yang juga dilakukan pada bulan yang sama dan tempat yang sama dengan aktivitas nyadran. Masyarakat Kepetingan lebih suka meyebutkan ritual ziarah kuburnya sebagai ziarah makam saja.

Salah satu informan dari desa Balongdowo yang mengikuti ritual nyadran pada tanggal 05 mei 2018 di makam Dewi Sekardadu menyatakan bahwa selama ini masyarakat sangat antusias mengikuti ritual kebudayaan nyadran karena percaya jika dengan mengikuti nyadran tangkapan kupang mereka akan semakin meningkat dan cuaca di laut akan selalu bersahabat dengan mereka saat mereka pergi melaut. Sebaliknya, jika mereka tidak mengikuti nyadran maka tangkapan kupang mereka akan menurun dan cuaca cenderung tidak bersahabat dengan mereka saat berada di laut. Berikut adalah dokumentasi Nyadran di makam Dewi Sekardadu:

Figure 1. Dokumentasi Nyadran

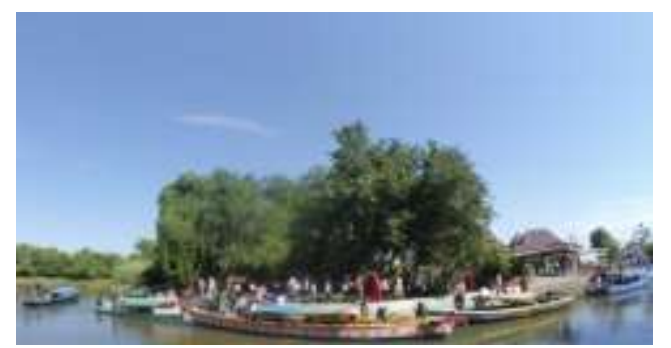

Sumber: Dokumentasi Penelitian

Kendati menghasilkan keuntungan tidak pernah euforia dengan nyadran. Bagi masyarakat Kepetingan, nyadran adalah kebudayaan masyarakat nelayan Sidoarjo, bukan masyarakat Kepetingan, yang lebih banyak berprofesi sebagai penjaga tambak ikan dan nelayan sungai. Masyarakat Kepetingan pada momen yang sama juga mengadakan ritual keagamaan yang mereka namai "Haul Dewi Sekardadu" untuk mengenang jasajasa Dewi Sekardadu sebagai isteri dan ibu dari seorang Wali.

Haul Dewi Sekardadu dipandang oleh masyarakat Kepetingan lebih religius dan dekat dengan Islam. Dalam ritus tersebut masyarakat melakukan doa bersama yang diawali dengan penampilan grup rabbana atau banjari, ceramah agama, dan berdoa bersama untuk kemakmuran warga Kepetingan yang ditutup dengan saling berbagi makanan.

Abdulloh Hanif dalam penelitiannya yang berjudul "Tradisi Peringatan Haul dalam Pendekatan Sosiologi Pengetahuan Peter L. Berger" mendefinisikan haul sebagai salah satu ritual dalam agama Islam yang bertujuan untuk memperingati hari kematian seseorang yang dianggap penting dalam sejarah Islam (Hanif, 2016). Penelitian yang dilakukan menemukan fakta haul yang menyediakan realitas lintas dunia, karena mayat yang diperingati, dihadirkan secara sosial melalui sejarah kehidupannya. Haul juga menampilkan sebuah motif yang unik dari masyarakat, yaitu motif agama yang diaplikasikan melalui cara yang tidak murni agama, yaitu refleksi sejarah. Meskipun secara keseluruhan, haul lebih banyak bernuansa agama, kecuali hanya refleksi sejarah sebagai acara intinya saja. Di samping sebagai tindakan sosial, haul juga merupakan tindakan agama. Sehingga apa yang kita katakan tentang ritual sosial keagamaan adalah sebuah ritual keagaman yang dilakukan secara 
sosial; mengandung motif agama; namun tujuan intinya tampak tidak murni agama, akan tetapi menyediakan makna-makna agama yang dapat diambil untuk memperbaiki kualitas keagamaan. Yang terakhir, haul adalah realitas sosial, karena masyarakat menerimanya sebagaimana adanya.

Pada momen Haul ini lah Sosok Dewi Sekardadu disosialisasikan pada masyarakat. Menurut masyarakat, setiap tahun atau setiap ritual Haul, siapa saja kyai, ustad atau pemuka agama yang memimpin ritual, pasti akan bercerita mengenai kisah Dewi Sekardadu. Informan penelitian yang sudah tinggal sejak lahir di Kepetingan menjelaskan:

"Setiap haul memang selalu bercerita tentang nyai Dewi, tapi kyai yang ini agak tidak setuju saya, sejarahnya berbeda sama yang diceritakan mbah buyut saya. Nyai Dewi tidak dibawa ikan keting, tetapi ditemukan pelaut dan dimakamkan di sini (informan inisial A. Pada o3 mei 2018 di dusun Kepetingan)."

Ikan keting yang dimaksud oleh informan di atas adalah sejenis ikan lele yang berukuran lebih kecil dan banyak ditemukan di sungai Kepetingan. Menurut Kyai Haji berinisial M dari desa Wonoayu, Sidoarjo, yang pada saat itu sebagai pemimpin Haul, ikan-ikan keting tersebut secara ajaib bisa membawa jasad Dewi Sekardadu yang mengapung di laut ke sebuah tempat yang pada akhirnya dinamakan Ketingan atau yang dimaksud adalah dusun Kepetingan. Cerita mengani ikan-ikan keting ajaib tersebut adalah yang paling populer bagi masyarakat Sidoarjo dan wisatawan, meskipun ada beberapa warga sekitar yang masih menyangsikan kebenaran dari cerita tersebut.

Dusun Kepetingan, atau yang dulu dinamai Peketengan di era kolonial bukan sebuah perkampungan atau pemukiman, apalagi perkampungan muslim. Jika dilihat dari peta digital di tahun 1884 sampai 1900an, makam Dewi Sekardau belum ditemukan di dusun tersebut, dan yang ada adalah kontor reserse milik Hindia Belanda, seperti pada gambar berikut:

Figure 2. Peta Sidoarjo Tahun 1884

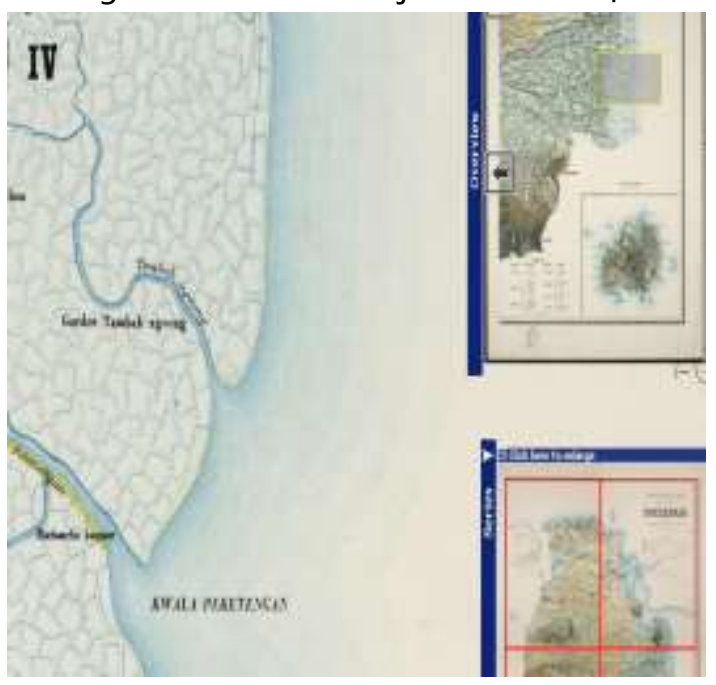

Sumber: (Universiteit, 2020)

Menurut cerita tutur yang berkembang, dusun Kepetingan atau Peketengan di era kolonial adalah tempat persinggahan nelayan, bandar perjudian, terdapat komplek lokalisasi, dan pelarian para kriminal. Hal ini dibenarkan oleh kepala Dusun Kepetingan yang pernah mendengar kisah tersbut dari kakeknya bahwa konon Kepetingan adalah bandar segala bandar. Mulai dari bandar judi, bandar ikan, dan bandar-bandar yang lain. Kepala Dusun Kepetingan hanya pernah mendengar, tetapi tidak berani memastikan kebenarannya karena tidak menyaksikan sendiri sejarah tersebut.

Sampai saat ini tidak ada yang tahu pasti kapan makam Dewi Sekardadu ada di Kepetingan. Bahkan, mayoritas masyarakat Kepetingan yang didominasi oleh pendatang dari Gresik dan Lamongan juga tidak mengetahui sejak kapan kakek buyut dan nenek buyut mereka mendiami Dusun Kepetingan. Mereka hanya mengetahui bahwa terlahir sebagai muslim dan menjalankan ajaran-ajaran Islam yang didapat oleh kakek buyut dan 
nenek buyut mereka dari Walisongo, yang di dalamnya termasuk Sunan Giri.

Masih dalam cerita tutur mengenai sejarah makam Dewi Sekardadu dari ketua Nyadran Desa Bluru Kidul, bahwa makam Dewi Sekardadu yang asli tetap berada di komplek pemakaman Sunan Giri di Gresik. Pada jaman dahulu Sunan Giri pernah diberi petunjuk bahwa ibunya telah meninggal dunia dan jasadnya berada di Kepetingan, sehingga secara ajaib keesokan harinya muncul gundukan tanah di komplek pemakaman Sunan Giri yang sekarang juga diyakini sebagai makam Dewi Sekardadu yang asli.

Kekuatan masyarakat kepetingan dalam melakukan komunikasi pariwisata sudah dapat merubah persepsi masyarakat terhadap makam Dewi Sekardadu sebagai bagian dari makam yang mempunyai karomah dapat mempercepat membantu tercapainya hajat peziarah tentunya dengan beberapa ritual yang dilakukan. Inilah daya tarik utama dibalik perjalanan ziarah muslim yang datang. Tentu upaya ini memerlukan waktu yang cukup lama mengingat lokasi makam Dewi Sekardadu berada di tengah pertambakan yang sulit untuk di kunjungi.

Namun hasil dari komodifikasi terhadap makam Dewi Sekardadu, hasilnya sudah dapat dirasakan dengan bergesernya pendapatan masyarakat sekitar dari awalnya hanya mengandalkan sebagai buruh tambak sudah bergeser menjadi pedagang makanan, minuman, pernak pernik cindra mata, dan sebagian lagi fokus pada persewaan sarana transportasi peziarah berupa perahu.

Dalam pandangan teori konstruksi realitas sosial Peter L. Berger dan Thomas Luckmann, fenomena legitimasi religius yang terjadi di dusun Kepetingan di atas adalah tahapan eksternalisasi atau yang disebut sebagai pembentukan kenyataan obyektif. Pengetahuan yang masuk akal atau obyektif adalah pengetahuan yang dimiliki secara bersama-sama dengan masyarakat dalam rutinitas kehidupan sehari-hari. Kenyataan mengetahui pengetahuan ini sangat sulit untuk disangsikan karena sudah menjadi kebiasaan hidup atau rutinitas dalam kehidupan bermasyarakat (Berger \& Luckmann, 1990).

Kenyataan obyektif tentang Dewi Sekardadu dalam komunikasi pariwisata yang berkembang adalah seorang isteri dari Maulana Ishaq, yang merupakan salah satu dari Walisongo, dan ibu kandung dari Sunan Giri, yang juga merupakan salah satu dari Walisongo. Ada satu identitas dari Dewi Sekardadu yang tidak ditonjolkan, yakni putri tunggal dari raja Blambangan.

Nilofar dalam bukunya yang berjudul Cerita Dewi Sekardadu menyebutkan bahwa Dewi Sekardadu hidup dan meninggal pada abad ke 14 sebagai seorang putri "anak tunggal" dari Minak Sembuyu, seorang Raja dari kerajaan Blambangan, yang merupakan salah satu kerajaan Hindu besar di pulau Jawa karena masih memiliki kekerabatan dengan kerajaan Majapahit (Nilofar, 2016).

Perbedaan pengetahuan dan pendapat mengenai sosok Dewi Sekardadu tidak hanya terjadi pada masyarakat. Buku yang ditulis oleh Sungkowati pada tahun 2011 dan Nilofar pada tahun 2016 memiliki perbedaan dalam memahami identitas Dewi Sekardadu. Sungkowati dkk menyatakan bahwa Dewi Sekardadu bukan hanya seorang putri kerajaan Blambangan, isteri Maulana Ishag, dan ibu dari Sunan Giri. Lebih dari itu, Dewi Sekardadu adalah pendakwah atau penyebar agama Islam di pesisir Sidoarjo (Sungkowati et al., 2011). Begitu juga mengenai sejarah meninggalnya Dewi Sekardadu. Nilofar menyatakan bahwa jasad Dewi Sekardadu 
ditemukan di laut oleh nelayan Sidoarjo saat sedang mencari ikan dan kemudian dimakamkan di dusun Kepetingan (Nilofar, 2016). Sedangkan menurut Sungkowati dkk, Dewi Sekardadu sampai di pesisir Sidoarjo menggunakan perahu kecilnya ketika sedang mencari anaknya (Sunan Giri) yang sengaja dihanyutkan ke laut oleh patih kerajaan Blambangan dan ayah Dewi Sekardadu karena dianggap sebagai ancaman terhadap eksistensi agama Hindu yang ada di Blambangan. Ketika sampai di perkampungan tersebut, Dewi Sekardadu menyebarkan ajaran Islam hingga meninggal dunia dan dimakamkan di daerah tersebut (Sungkowati et al., 2011).

Dalam kenyataan obyektif, Dewi Sekardadu pada akhirnya lebih diyakini sebagai salah satu tokoh Islam di Jawa Timur. Menurut Kepala Dusun Kepetingan, peziarah di luar Sidoarjo yang sering berkunjung berasal dari Gresik, Lamongan, Madura, Jombang, Mojokerto, dan beberapa daerah di Jawa Timur lainnya.

Ritual yang dilakukan pada umumnya sama, yakni berdoa di depan makam Dewi Sekardadu sembari menyampaikan hajat atau keinginan. Menurut Juru Kunci makam (bapak Samadi), banyak tamu berdatangan terutama menjelang ramadhan dan hari raya idhul fitri karena Dewi Sekardadu dianggap sebagai sesepuh atau leluhur Islam di daerah tersebut. Pendapat bapak Samadi didukung oleh pernyataan informan yang menyatakan bahwa:

"Kami datang kesini karena sudah nadhar mau tawassul dan ziarah mas. Anak saya lancar lahirannya sesar, bayi dan ibunya sehat. (Informan atas nama Sumari, warga desa Kebonsari, Candi, Sidoarjo, di makam Dewi Sekardadu, pada 14 Maret 2020, pukul 11.10)".
Ritual oleh satu keluarga di atas dilakukan karena informan sudah berjanji jika operasi sesar anaknya berjalan lancar, satu keluarga akan berziarah dan berdoa di makam Dewi Sekardadu. Tidak hanya itu, peziarah tersebut juga membawa tumpeng untuk dibagikan pada masyarakat sekitar sebagai wujud rasa syukur mereka.

Dalam pandangan ilmu sosial, agama adalah suatu usaha manusia dalam membentuk suatu kosmos keramat. Dengan kata lain, agama merupakan kosmisasi dalam suatu acara yang keramat atau sakral. Hal ini berhubungan dengan ruang dan waktu seperti lokalitas-lokalitas keramat dan musim-musim keramat tertentu (Berger, 1991).

\section{Obyektivasi Masyarakat Kepetingan}

Komunikasi pariwisata yang dibangun masyarakat dalam Obyektivasi adalah interaksi intersubyektif melalui proses pelembagaan atau institusionalisasi. Obyektivitas dunia kelembagaan adalah obyektivitas yang dibuat dan dibangun oleh manusia. Eksternalisasi dan obyektifikasi merupakan momen-momen dalam suatu proses dialektis yang berlangsung secara terus-menerus. Dengan demikian masyarakat merupakan produk manusia atau dengan kata lain masyarakat adalah produk sosial (Dharma, 2018).

Kenyataan obyektif tentang Dewi Sekardadu yang telah disosialisakan pada masyarakat pada akhirnya taken for granted bagi masyarakat Kepetingan. Masyarakat tidak pernah mempermasalahkan asal-usul atau sejarah Dewi Sekardadu selama masih berhubungan dengan agama Islam, karena $100 \%$ penduduk dusun Kepetingan beragama Islam.

Faktor lain yang membuat masyarakat Kepetingan terkesan menerima begitu 
saja kenyataan tentang Dewi Sekardadu adalah kenyataan bahwa mereka adalah pendatang. Sebagian besar penduduk Kepetingan berasal dari Gresik dan Lamongan. Juru kunci makam Dewi Sekardadu pun berasal dari Mojokerto.

Menurut Kepala Dusun (Kasun) Kepetingan, masyarakat Kepetingan didominasi oleh masyarakat dari Gresik, termasuk juga garis keturunan keluarga informan. Kepetingan, seperti yang diketahui oleh Kasun dahulunya sebuah bandar atau pasar ikan besar. Banyak nelayan dari berbagai daerah di Jawa Timur yang singgah di daerah tersebut untuk menjual hasil tangkapan ikannya.

Pendapat di atas ditambahkan oleh informan yang juga sering melakukan perdagangan ikan di Kepetingan. Menurut informan berinisial G dari Sidoarjo, Kepetingan dahulunya hanya sebuah tambak-tambak ikan tanpa perkampungan. Penduduk dari Gresik dan Lamongan sengaja didatangkan oleh pemilik-pemilik tambak ke Kepetingan untuk menjaga tambak-tambak tersebut karena dinilai mahir mengelolah tambak ikan di daerah asalnya. Dari sana lah terjadi perkawinan dengan penduduk Sidoarjo dan terbentuklah sebuah perkampungan di Kepetingan.

Selain itu, konstruksi realitas Dewi Sekardadu sebagai tokoh Islam sejalan dengan keinginan masyarakat Kepetingan yang justru menonjolkan sisi islami dalam sosok Dewi Sekardau daripada mencari tahu hubungan Dewi Sekardadu dengan kerjaan Hindu. Beberapa informan yang diwawancarai menyebutkan jika adatistiadat atau ritual di makam Dewi Sekardadu selalu dilakukan dengan cara dan budaya Islam. Bahkan, masyarakat dusun Kepetingan tidak pernah mengikuti nyadran karena dinilai kurang islami. Masyarakat dusun Kepetingan sebagai tuan rumah dari acara nyadran hanya menyambut peserta nyadran dengan ramah sebagaimana mestinya, tanpa ada keinginan untuk mengikuti prosesi ritual tersebut.

Istilah nyadran sebenarnya tidak jauh dari ritual dalam agama Islam masyarakat Jawa. Tradisi nyadran pada umumnya merupakan hasil dari proses asimilasi budaya yang melibatkan tiga agama; Islam, Hindu, dan Budha. Dalam agama Hindu-Budha, nyadran identik dengan Sharadda atau Meruwat, yakni budaya berziarah ke makam leluhur, yang kemudian dijadikan sebagai pendekatan dakwah oleh beberapa pendakwah agama Islam di tanah Jawa dengan mengubah serta menetapkan momentum berziarah pada akhir bulan Ruwah atau hari-hari menjelang datangnya bulan ramadhan (Hartoyo, 2017).

Dengan dalih ingin memisahkan nilainilai Islam dari pengaruh kebudayaan maupun tradisi yang sudah melekat di dalam kehidupan masyarakat sekitar dusun Kepetingan, masyarakat dusun Kepetingan justru terjebak dengan desakralisasi yang mereka lakukan terhadap makam Dewi Sekardadu. Hal ini dapat dilihat dari bentuk makam yang lebih menyerupai monument daripada makam manusia.

\section{Internalisasi: Antara Mistis atau Ekonomis}

Untuk mencapai internalisasi, individu akan terlebih dahulu mendapatkan sosialisasi, yang dapat diidentifikasikan sebagai pengimbasan individu secara komprehensif dan konsisten ke dalam duia obyektif suatu masyarakat atau salah satu sektornya. Sosialisasi sendiri dibagi menjadi dua: primer dan sekunder. Sosialisasi primer adalah sosialisasi yang paling pertama dialami oleh individu, yaitu pada masa kanak-kanak, yang dengan itu ia menjadi anggota masyarakat. 
Sedangkan sosialisasi sekunder adalah proses-proses lanjutan yang mengimbas individu yang sudah tersosialisasi itu ke dalam sektor-sektor baru dunia obyektif masyarakatnya (Berger \& Luckmann, 1990).

Dalam komunikasi pariwisata masyarakat Kepetingan, Sosok Dewi Sekardadu disosialisasikan oleh masyarakat dusun Kepetingan secara primer dan sekunder. Dalam sosialisasi primer, setiap anak kecil yang ada di Kepetingan sudah tahu bahwa makam Dewi Sekardadu adalah keramat dan bersejarah. Lebih dari itu, ada rasa bangga yang ditanamkan pada anak-anak karena dusun Kepetingan memiliki situs Debwi Sekardadu.

Anak-anak diajarkan baca tulis Al Qur'an sejak dini oleh masing-masing keluarga agar dekat dengan agama Islam. Begitu pula pengetahuan tentang haul dan ritual-ritual yang melibatkan makam Dewi Sekardadu. Sejak kecil anak-anak selalu diajak menghadiri haul Dewi Sekardadu. Dalam acara tersebut anak-anak merasa senang karena ada pembagian makanan secara gratis. Selain itu juga diajarkan pula pada anak-anak cara memainkan rebbana sambil melantunkan salawat pada Nabi Muhammad SAW dengan harapan anakanak dusun Kepetingan dapat memainkan rebbana saat ada ritual di makam Dewi Sekardadu, termasuk saat haul.

Sosialisasi primer di atas akan berakhir ketika konsep tentang orag lain pada umumnya telah terbentuk dan tertanam dalam kesadaran individu. Pada titik ini anak-anak telah tumbuh dewasa menjadi angota efektif masyarakat dan secara subyektif memiliki suatu diri dan sebuah pandangan dunia. Kendati demikian, sosialisasi tidak terjadi sekali ini saja. Bagaimana sosialisasi primer itu dipertahankan oleh individu dan bagaimana sosialisasi sekunder akan berlangsung sesudahnya.

Selanjutnya manusia akan mengalami sosialisasi sekunder. Sosialisasi ini dapat dipahami sebagai internalisasi sejumlah "subdunia" kelembagaan atau yang berlandaskan lembaga. Oleh karena itu, lingkup jangkauan dan sifatnya ditentukan oleh kompleksitas pembagian kerja dan distribusi pengetahuan dalam lingkungan sosial yang ditempati atau yang dalam hal ini kita sebut sebagai eksternalisasi.

Internalisasi sosok Dewi Sekardadu dalam masyarakat Kepetingan berbedabeda. Sebagian masyarakat Kepetingan percaya pada hal mistis, seperti roh Dewi Sekardadu yang masih berada di makamnya. Jika ada yang berhasil menemuinya dalam pertapaan, maka seseorang tersebut akan mendapatkan kanujela atau kuasa ajaib bisa menyebuhkan berbagai macam jenis penyakit.

Juru kunci makam membenarkan temuan di atas. Bapak Samadi yang sudah 25 tahun menjadi juru kunci sering menemukan peziarah yang berniat untuk mendapatkan wangsit dari makam Dewi Sekardadu dalam hal menyembuhkan penyakit dan kelancaran rejeki.

Bapak Samadi sendiri diangkat menjadi juru kunci karena dianggap yang paling tua di dusun tersebut, bukan pada pengetahuannya. Menurut informan lainnya, bapak Samadi sendiri kurang memahami makam Dewi Sekardadu karena bukan termasuk warga lokal.

Sebagian masyarakat Kepetingan mengalami internalisasi yang berbeda. Kendati tetap mempercayai Dewi Sekardadu sebagai tokoh Islam, masyarakat dalam jenis ini lebih mengutamakan realitas ekonomi dari makam Dewi Sekardadu.

Berger menjelaskan bahwa legitimasi relijius memiliki beberapa keuntungan 
yang dapat dilihat melalui titik pandang obyektifitas kelembagaan maupun dari sudut pandang kesadaran subyektif individual. Realitas yang dibangun berdasarkan nilai-nilai relijius tidak terelakkan, memiliki kemantapan dan tahan lama dengan kualitas-kualitas realitas yang dilekatkan pada Tuhan (Berger, 1991).

Masalah serius yang dihadapi oleh legitimasi relijius ini ialah situasi pluralistik dari masyarakat yang tidak terbatas pada aspek-aspek struktural-sosial. Akibatakibatnya juga mempengaruhi kandungan relijius, yaitu mempengaruhi produk pelaku-pelaku pemasaran relijius. Legitimasi relijius dapat dimonopoli oleh masyarakat untuk motif tertentu. Kandungan-kandungan relijius yang dilembagakan bisa ditentukan oleh tokohtokoh agama menurut apapun kandungan relijius yang tampak nalar. Dengan demikian agama selalu rentan dengan pengaruh-pengaruh yang bermotif duniawi (Berger, 1991).

Pendapat Berger terjadi di Kepetingan. Masyarakat dusun Kepetingan sudah memiliki peziarah prospectus yang secara rutin berziarah ke makam Dewi Sekardadu. Beberapa penduduk yang memiliki modal, baik modal agama, materi, dan sosial, berusaha mencari dan melayani peziarah yang datang dengan baik. Pelayanan yang diberikan ialah penjemputan menggunakan perahu, penyediaan catering atau jamuan makan, dan penginapan, sehingga membuat peziarah akan selalu menghubungi individu tersebut ketika ingin berkunjung atau berziarah ke makam Dewi Sekardadu.

Fenomena di atas adalah tindakan manusia yang menciptakan sebuah sejarah, saat mereka berinteraksi dengan alam dan organisasi kerja mereka untuk memenuhi kebutuhan fisik atau ekonomi (Clark \& Foster, 2006).

Secara kelembagaan, wacana untuk menjadikan dusun Kepetingan sebagai daerah wisata religi yang berbasis masyarakat sudah ada sejak tahun 2000an dan semakin gencar diwacanakan pada tahun 2015 dan 2018. Wacana tersebut didasarkan pada minat dan antusias masyarakat Jawa Timur terhadap wisata ziarah kubur, dan fenomena alam, yakni adanya hamparan tanaman mangrove di sepanjang jalur air menuju dusun Kepetingan.

Modal social-budaya dan alam tersebut juga didukung oleh pemerintah dengan mengadakan dan memperbaiki beberapa fasilitas yang menunjang seperti pavingisasi dan perbaikan jalan darat menuju dusun Kepetingan, mempercantik Makam Dewi Sekardadu, memberikan 3 perahu, dan membuatkan dermaga untuk perahu yang mengantar dan menjemput peziarah.

Kendati demikian, masyarakat sekitar belum memaksimalkan potensi yang ada untuk mengembangkan wisata eko-religi di dusun Kepetingan. Beberapa fasilitas terlihat tidak terawat dengan baik. Salah satunya adalah adalah dermaga sebelah Timur, yang digunakan oleh peserta ritual nyadran untuk melabuhkan perahu mereka.

Selain kurangnya perawatan fasilitas yang ada, juga tidak terjalin koordinasi yang baik antar warga. Masyarakat secara mandiri mencari pengunjung prospectus dengan membuka layanan antar jemput peziarah, catering, hingga jasa penginapan secara mandiri. Mereka belum terkoordinasikan secara bersama-sama untuk membentuk kelompok sadar wisata sehingga wisata religi makam Dewi Sekardadu hanya dinikmati oleh masyarakat yang memiliki modal lebih. 
Tidak adanya koordinasi yang baik antar warga juga mengakibatkan wisata religi di dusun Kepetingan sama dengan ziarah kubur pada umumnya. Peziarah hanya datang berziarah dan pulang tanpa ada sesuatu yang di bawa atau oleh-oleh khas dusun Kepetingan.

Beberapa oleh-oleh yang dimaksud oleh peziarah misalnya baju bergambar atau bertuliskan Dewi Sekardadu, gantungan kunci, produk makanan khas dusun Kepetingan, atau apa saja yang dapat mengingatkan wisatawan terhadap makam Dewi Sekardadu.

Dalam komunikasi pariwisata, bentuk lokalitas di atas disebut sebagai local branding. Nugraha, Perbawasari, \& Zubair (2017) dalam penelitiannya menyebutkan bahwa local branding memiliki kekuatan yang besar dalam pengembangan pariwisata berbasis kearifan lokal. Karenanya, kreatifitas dari stakeholder sangat dibutuhkan dalam mengkomunikasikan bentuk-bentuk kearifan lokal setempat melalui media informatif dan integratif.

Pemangku kepentingan yang ada di Kepetingan mengakui bahwa ada kelemahan dalam memahami komunikasi pariwisata yang sudah dijelaskan di atas. Mereka berharap akan adanya setting sosial, misalnya diadakan pelatihanpelatihan komunikasi pemasaran pariwisata dan kemudian dibuatkan sentra Pedagang Kaki Lima (PKL) khusus warga dusun Kepetingan agar semakin banyak masyarakat yang merasakan dampak ekonomi dari adanya wisata religi makam Dewi Sekardadu. Selama ini mayoritas masyarakat berprofesi sebagai penjaga tambak-tambak ikan dan nelayan rawarawa atau sungai, sehingga ekonomi mereka bergantung pada alam.

Patrick J. Holladay dan Robert B. Powell telah meneliti pengembangan pariwisata untuk mengatasi kemiskinan di
Republik Dominika. Bagi Holladay dan Powell, keberlangsungan pariwisata komunitas dapat ditingkatkan melalui penguatan beberapa daerah ketahanan. Pertama, penduduk setempat yang berpartisipasi dalam pariwisata berbasis masyarakat perlu memiliki kekuatan untuk membangun investasi awal yang berasal dari program pengembangan pariwisata. Dari perspektif ketahanan, ini berarti bahwa penduduk lokal membutuhkan kekuatan untuk mandiri dan mengatur diri (Patrick J. \& Powell B., 2016).

Hal ini membutuhkan perubahan dalam pemerintahan top-down. Lebih lanjut, penduduk setempat membutuhkan pelatihan tambahan untuk meningkatkan pemahaman mereka tentang industri pariwisata dan peningkatan sumber daya manusia. Satu langkah lebih jauh, upaya edukasi untuk mengatasi keengganan budaya lokal untuk berpartisipasi dalam berbagi pengetahuan dan belajar. Tanpa hal ini mungkin ada beberapa implikasi negatif untuk keberhasilan bagi masyarakat yang merupakan bagian dari industri pariwisata berbasis masyarakat.

John Aloysius Zinda dkk dalam penelitian yang dilakukan di wilayah pedesaan China juga menyampaikan adanya setting sosial untuk mengoptimalkan pariwisata pada peningkatan ekonomi masyarakat desa. Dasar argumen yang diambil ialah demi terciptanya pembangunan desa dengan mengelolah sumber daya alam yang ada di masing-masing daerah. Menjadi umum ketika penembangan pariwisata dikaitkan dengan pembangunan desa atau memakmurkan masyarakat di sekitarnya. Oleh karena itu, penelitiannya difokuskan pada penggunaan sumber daya alam, mata pencaharian masyarakat, hasil hutan non-kayu yang dikelolah, dan pertanian 
China (Zinda Aloysius, Yang, Xue, \& Cheng, 2014).

Di Xidang, masyarakat lebih fokus pada peternakan keledai, sementara di Yubeng masyarakatnya tidak hanya peternak keledai, namun juga konsen dalam pembangunan wisama-wisma bagi turis. Keduanya ini tidak terjadi di daerah penelitian lainnya, kecuali di Sidong dengan pembangunan beberapa wisma. Untuk daerah yang ain, masyarakat lebih suka mengembangkan hasil pertanian mereka karena alam mereka terbukti subur dan terjaga. Dalam hal ini tidak ada perubahan budaya kerja yang signifikan dari masyarakat. Secara umum mereka masih bekerja menjadi petani dan peternak. Bedanya, mereka lebih mudah menjual hasil ternak dan hasil bumi mereka sejak ada pariwisata di daerah mereka. Intinya, pariwisata tidak merubah ekosistem yang ada karena secara pribadi masyarakat sadar bahwa kehidupan mereka tetap ditopang oleh hasil alam.

Penataan seperti di atas menjadi penting untuk memaksimalkan potensi pariwisata yang ada di Kepetingan. Komoditas ikan yang ada di Kepetingan bisa dihidupkan kembali sebagai komoditas utama dalam menunjang wisata eko-religi Dewi Sekardadu. Cerita rakyat mengenai bandar ikan Kepetingan berpotensi hidup kembali berdampingan dengan pengembangan pariwisata berbasis rakyat miskin di dusun Kepetingan.

\section{Kesimpulan}

Hasil studi ini adalah konstruksi realitas yang dilakukan oleh masyarakat terhadap makam Dewi Sekardadu dalam komunikasi pariwisata pro-poor dilakukan dengan tiga tahap (ekternalisasi, obyektivasi, internalisasi). Dalam tahap eksternalisasi komunikasi pariwisata lebih menonjolkan sisi Islami dari Dewi
Sekardadu. Sosok Dewi Sekardadu lebih didekatkan dengan tokoh besar agama Islam tanah Jawa, yaitu Istri dari Maulana Ishaq dan ibu dari Sunan Giri melalui ritual keagamaan haul Dewi Sekardadu. Tahap obyektif komunikasi pariwisata berusaha membangun Makam Dewi Sekardadu sebagai kenyataan obyektif yang telah dikonstruksi taken for granted bagi masyarakat Kepetingan karena 100\% masyarakat Kepetingan beragama Islam dan mayoritas penduduknya adalah pendatang, termasuk juru kunci makam.Pada tahap internalisasi komunikasi pariwisata yang dikembangkan dengan menjadikan makam Dewi Sekardadu sebagai komoditas pariwisata masyarakat sekitar utamanya masyarakat berusia dewasa. Dengan adanya komunikasi pariwisata akan menunjang pengetahuan masyarakat dalam wisata religi, memenuhi fasilitas penunjang pariwisata serta meningkatkan pendapatan masyarakat sekitar yang saat ini masih berprofesi sebagai penjaga tambak ikan dan nelayan sungai karena kurangnya sosialisasi dan pelatihan manajemen pariwisata dari pemerintah.

Pada tahap internalisasi komunikasi pariwisata memunculkan dua pandangan yang menguat terkait pengembangan pariwisata di Kepetingan, yakni sisi keramat atau mistis dari makam Dewi Sekardadu dan sisi ekonomis dari pengembangan pariwisata. Selama ini fasilitas-fasilitas pariwisata yang telah diberikan pemerintah hanya dimanfaatkan oleh beberapa warga yang memiliki modal sosial dan ekonomi sehingga tidak dapat memperbaiki keadaan ekonomimasyarakat Kepetingan yang mayoritas berprofesi sebagai penjaga tambak ikan dan nelayan rawa-rawa atau sungai. Hal ini terjadi karena kurangnya pengetahuan masyarakat Kepetingan pada potensi wisata dan pemanfaatkan 
fasilitas pariwisata yang ada di Kepetingan.

\section{Referensi}

Bakti, I., Sumartias, S., Damayanti, T., \& Nugraha, A. R. (2018).

Pengembangan Model Komunikasi Pariwisata Berbasis Kearifan Lokal di Kawasan Geopark Pangandaran. Jurnal Kajian Komunikasi, 6(2), 217. https://doi.org/10.24198/jkk.v6i2.184 59

Berger, P. L. (1991). Langit Suci: Agama Sebagai Realitas Sosial (Hartono, Ed.). Jakarta: LP3ES.

Berger, P. L., \& Luckmann, T. (1990). Tafsir Sosial atas Kenyataan: Risalah tentang Sosiologi Pengetahuan $(\mathrm{H}$. Basari, Ed.). Jakarta: LP3ES.

Clark, B., \& Foster, J. B. (2006). The Environmental Conditions of The Working Class: An Introduction to Selections from Frederick Engels's The Condition of the Working Class in England in 1844. Organization \& Environment, 19(3), 375-388.

Dharma, F. A. (2018). Konstruksi Realitas Sosial : Pemikiran Peter L. Berger Tentang Kenyataan Sosial. Kanal: Jurnal Ilmu Komunikasi, 7(1), 1-9. Retrieved from https://journal.umsida.ac.id/index.ph p/kanal/article/view/101

Hanif, A. (2016). Tradisi Peringatan Haul Dalam Pendekatan Sosiologi Pengetahuan Peter L. Berger. Dialogia, 13(1), 49-58.

Hartoyo. (2017). The Study of the Social Realities of the Nyadran Tradition Among Fishing Communities. Nternational Journal of Information Research and Review, 04(04), 39944000.

Harvie, F. (2011). Handbook of Social Theory (G. Ritzer, Ed.). London: SAGE Publications.

Nilofar, N. (2016). Cerita Dewi Sekardadu; Cerita Rakyat dari Jawa Timur. Jakarta
Timur: Badan Pengembangan dan

Pembinaan Bahasa.

Nugraha, A. R., Perbawasari, S., \& Zubair, F. (2017). Model Komunikasi Pariwisata Yang Berbasiskan Kearifan Lokal. Jurnal The Messenger, 9(2), 231.

https://doi.org/10.26623/themesseng er.vgi2.468

Patrick J., H., \& Powell B., R. (2016). Social-Ecological Resilience And Stakeholders: A Qualitative Inquiry Into Community-Based Tourism In The Commonwealth Of Dominica. Caribbean Studies, 44(1/2 (JanuaryDecember 2016)), 3-28.

Prasetyanti, R. (2017). Channelling urban modernity to sustainable pro-poor tourism development in Indonesia. IOP Conference Series: Earth and Environmental Science, 70(1). https://doi.org/10.1088/17551315/70/1/012059

Rukin. (2020). ECONOMIC DEVELOPMENT OF COASTAL VILLAGE COMMUNITIES. Jurnal Sosial Humaniora, 11(1), 1-14.

Sungkowati, Y., Mashuri, Asmara, A., Izzak, A., Turaeni, N. N. T., Sukmawati, D. L., ... Ummatin, K. (2011). Antologi Cerita Rakyat Jawa Timur (1st ed.; S. Kasiyun \& T. Winasih, Eds.). Sidoarjo: Balai Bahasa Surabaya.

Universiteit, L. (2020). Dutch Colonial Maps. Retrieved July 20, 2020, from Leiden Universiteit website: maps.library.leiden.edu/cgibin/iipview?krtid=3985\&name $=05057$ -5.JPG\&marklat=-

$7 \cdot 44541 \&$ marklon $=112.7181 \&$ sid $=$ n23 dds5412963\&seq $=2$ \& serie $=1$ \&lang $=1$ \&ssid $=\&$ resstrt $=0 \&$ svid $=566123 \&$ disp $\mathrm{x}=1280$ \&dispy $=686$ \#focus

Wirata, K. (2015). Kebijakan Pengelolaan Wisata Ekoreligi Berkelanjutan (R. Safa'at, Ed.). Malang: Surya Pena Gemilang. 
Zinda Aloysius, J., Yang, J., Xue, X., \& Cheng, H. (2014). Varying Impacts of Tourism Participation on Natural
Resource Use in Communities in Southwest China. Human Ecology, 42(5), 739751. 